\title{
New routes to the preparation of silver-soft liner nanocomposites as an antibacterial agent
}

\author{
Chul Jae Lee ${ }^{\mathrm{a}}$, Ki Young Nam ${ }^{\mathrm{b}}$, Dong Yeub Kim ${ }^{\mathrm{a}}$, Hee Jin Kim ${ }^{\mathrm{c}}$, Won Hui Doh ${ }^{\mathrm{d}}$, \\ Hyun Kuk Choi ${ }^{\text {, }}$ Maeng Joon Jung e,* \\ ${ }^{a}$ School of Chemical Industry, Yeungnam College of Science E Technology, Daegu 705-703, Republic of Korea \\ ${ }^{\mathrm{b}}$ Department of Dentistry, College of Medicine, Keimyung University, Daegu 700-712, Republic of Korea \\ ${ }^{\mathrm{c}}$ Department of Chemical Engineering, Pohang University of Science and Technology (POSTECH) San 31, Hyoja-Dong, Nam Gu, Pohang, Gyungbuk 790-784, \\ Republic of Korea \\ d Laboratoire LMSPC UMR7515, CNRS, University of Strasbourg, F-67087 Strasbourg cedex 2, France \\ e School of Nano E' Materials Science Engineering, Kyungpook National University, Sangju 742-711, Republic of Korea
}

\section{A R T I C L E I N F O}

\section{Article history:}

Received 21 January 2013

Accepted 2 July 2013

Available online 9 July 2013

\section{Keywords:}

Silver

Nanoparticles

Soft-liner

Antibacterial

E. coli

\begin{abstract}
A B S T R A C T
This study evaluated the antimicrobial and physical properties of silver-soft liner nanocomposites (AgSLN). Polymerized acrylic soft denture liner disk specimens containing 0 (control), 1500, 3000, or $6000 \mathrm{mg} / \mathrm{L}$ of silver nanoparticles were placed on the flat bottom of the separate 12-well cell culture plate dish and $100 \mu \mathrm{L}$ samples of microbial suspensions of Escherichia coli strain were inoculated on each specimen and incubated at $37^{\circ} \mathrm{C}$, for 24 and or $72 \mathrm{~h}$. The antimicrobial effects were determined according to the number of viable cells in the retrieved suspension. Characterization of silver nanoparticles was carried out based on UV-vis spectroscopy and transmission electron microscopy (TEM) analysis. The specimens were characterized by thermal gravimetric analysis (TGA), field emission scanning electron microscope and energy dispersive X-ray analysis (FE-SEM/EDAX), and atomic absorption spectroscopy (AAS). We successfully prepared Ag-SLN and identified the great excellent antimicrobial activity for $E$ coli.
\end{abstract}

( 2013 Published by Elsevier B.V. on behalf of The Korean Society of Industrial and Engineering Chemistry.

\section{Introduction}

New technologies require new materials with special combinations of properties. Recently, the surface modification of polymer materials has been a major challenge in medical applications such as implants or other devices in the human body [1]. Particularly in the oral cavity, acrylic soft denture liners have been commonly used to enhance the recovery of denturebearing tissues from trauma and damage, which are usually caused by ill-fitting dentures. However, lining materials have complicated molecular structures and are easily degradable, along with being susceptible to bacterial adhesion. The adhered bacteria can be released from denture plaque into salivary secretions and then aspirated into the lower respiratory tract, causing pneumonia, especially in elderly people or those with disabilities; such individuals have a diminished general immune response and pharyngeal reflex [2-6].

\footnotetext{
* Corresponding author. Tel.: +82 545301336; fax: +82 545365330 .

E-mail address: jmj@knu.ac.kr (M.J. Jung).
}

Systemic or local antibiotic agents have been prescribed to eliminate the bacterial population for treatment in cases of infection; however, as microbial resistance and healthcare costs are both increasing, the development of antimicrobial denture lining material could be necessary for the prevention and care of increased bacterial populations [7,8]. Although several in vitro and in vivo studies have shown the beneficial effects of antimicrobial agents combined in polymeric soft denture liners [9-11], no effective, commercial antimicrobial agent to be combined has yet been developed.

Silver nanoparticles are emerging as a new generation of antibacterial agent [12]; they have been used for hygiene [13], medical applications [14-16], and antibacterial water filters [17]. Recently, silver nanoparticles have shown superior antibacterial activity compared to that of other silver compounds, as well as bulk silver. Silver nanoparticles do not only possess strong antibacterial activity, but can also inhibit a broad spectrum of bacteria and fungi $[13,18]$. Although silver nanoparticles have been integrated with various materials, none of these works was carried out using soft liners (SLs). Therefore, the purposes of this study were to generate a new synthesis of silver-soft liner nanocomposites (Ag-SLN) and to assess its antimicrobial effects. 


\section{Experimental}

Silver nitrate $\left(\mathrm{AgNO}_{3}, 99.9 \%\right)$ was purchased from Kojima Chemicals Co. Ltd. (Japan). PVP (MW. avg. = 10,000) was obtained from Sigma-Aldrich Co. GC Soft-Liner was purchased from GC Co. Ltd. (Japan). All chemical reagents were used without further purification. Colloidal silver nanoparticles were prepared from the solutions of $0.3 \mathrm{M}$ of $\mathrm{AgNO}_{3}$ and $5 \mathrm{wt}$.\% PVP in distilled water. The whole preparation procedure can be explained as follows: $12.50 \mathrm{~g}$ of PVP was dissolved in $250 \mathrm{~mL}$ of distilled water; following this, $12.74 \mathrm{~g}$ of silver nitrate was added to the solution. Then, the solution changed in color from yellow to dark olive green. The chemical process continued for $2 \mathrm{~h}$ at room temperature.

The size of the silver nanoparticles was measured using transmission electron microscopy (TEM; Hitachi H-7100). The UV-vis spectra of the silver nanoparticles were recorded with a SCINO UV S-2100 UV-Vis spectrophotometer.

Determination of each Ag-SLN sample (about $1.0 \mathrm{~g}$ ) was dried under a vacuum until it maintained a constant weight and then placed in a flask. Distilled water $(50 \mathrm{~mL})$ was added to the flask and the mixture was shaken for about 24,48 , or $72 \mathrm{~h}$. The concentration of silver nanoparticles in the obtained solution was determined using atomic absorption spectroscopy (AAs; Perkin Elmer AAnalyst 100, USA). A silver hollow cathode lamp (Perkin-Elmer, USA) with a $328.1 \mathrm{~nm}$ line and $0.7 \mathrm{~nm}$ spectral band pass operated at $12 \mathrm{~mA}$ was the radiation source.

GC Soft-Liner (GC cooperation, Tokyo, Japan) was selected as a soft denture liner in this study. Doses of $\mathrm{Ag}^{\circ}$ added to the conditioner liquid are shown in Table 1. Colloidal $\mathrm{Ag}^{\circ}$ was preliminarily combined and homogenized with the conditioner liquid in a sterile glass beaker at a concentration ranging from 0 (control) to 1500,3000 , and $6000 \mathrm{mg} / \mathrm{L}$ (vol/vol; colloidal $\mathrm{Ag}^{\circ} /$ conditioner liquid). Acrylic powder was added and mixed for $30 \mathrm{~s}$ at a designated powder/liquid ratio following the manufacturer's instructions. To generate a uniform shape with a regular surface for samples, mixed conditioner paste was poured onto a custom-made brass mold with a hole $(20 \mathrm{~mm}$ diameter $\times 3.0 \mathrm{~mm}$ height), which sandwiched the paste between glass slides until the SL was solidified. Sixty specimens were prepared and divided into four groups $(N=15)$ according to the concentration of $\mathrm{Ag}^{\circ}$. Before microbial assay, all samples were sterilized with ethylene oxide gas for $24 \mathrm{~h}$ to ensure the initial sterility of samples. The microstructure of obtained Ag-SLN was studied by field emission scanning electron microscope (FE-SEM; Philips XL30S FEG) equipped with EDAX (Sapphire detector with LEAP + Crystals). The Ag-SLN was gold sputtered under high vacuum before the analysis. EDAX studies were also performed for Ag-SLN to identify the silver nanoparticles of the surfaces.

Thermal gravimetric analyses (TGA) were carried out simultaneously using a TG-DTA92 instrument (SETARAM, France) with a heating rate of $10^{\circ} \mathrm{C} \mathrm{min}{ }^{-1}$ from $30{ }^{\circ} \mathrm{C}$ to $600{ }^{\circ} \mathrm{C}$. Each sample was analyzed in triplicate and mean values were estimated.

Microbial suspensions were obtained from a single colony (Escherichia coli; ATCC 6538) isolated on agar plates and then inoculated in appropriate broth for overnight cultures. Bacterial strains were grown in brain-heart infusion (BHI; Difco, Franklin

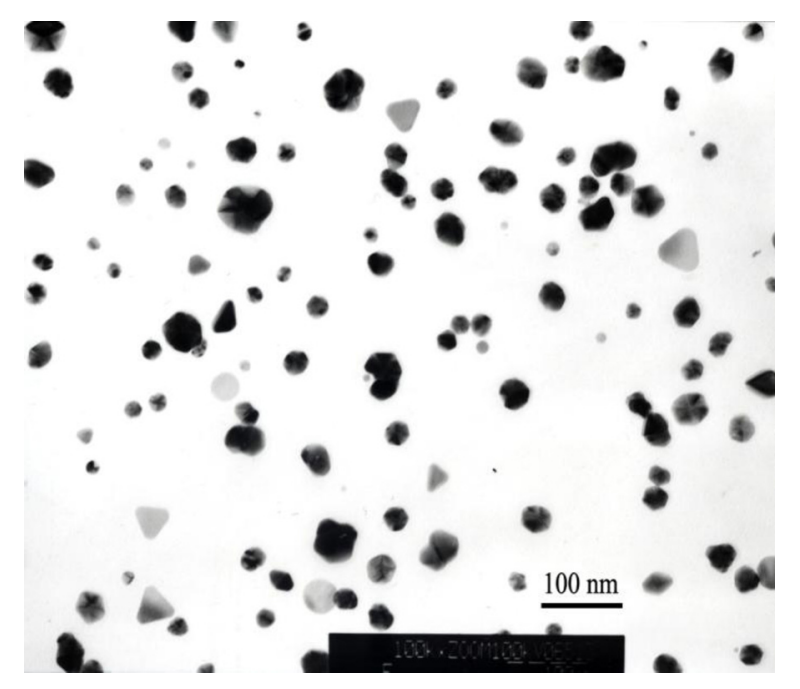

Fig. 1. TEM image of silver nanoparticles prepared by the in situ reduction method.

Lakes, NJ, USA) broth and onto Mueller Hinton agar plates at $37^{\circ} \mathrm{C}$. After incubating microbial cells at $37{ }^{\circ} \mathrm{C}$ overnight, the optical density (OD) of the suspension at $600 \mathrm{~nm}$ was adjusted to $1.0 \mathrm{using}$ a spectrophotometer (Milton Roy spectrophotometer 20D ${ }^{+}$, Milton Roy, Ivyland, USA). The suspension was diluted with phosphatebuffered saline ( $\mathrm{pH} 7.4)$ to $1: 100$ and suspended to final concentration of $1.0 \times 10^{7}$ cells/mL $[19,20]$.

Samples of Ag-SLN and control were placed on the flat bottom of separate 12 well cell culture plates (Costa ${ }^{\mathbb{R}}$, Corning, New York, USA), and then $100 \mu \mathrm{L}$ of the initial microbial suspension in $1.0 \mathrm{~mL}$ of Sabouraud broth was inoculated in each well and incubated at $37^{\circ} \mathrm{C}$. After incubation for $24 \mathrm{~h}$ and $72 \mathrm{~h}$ for an extended contact period, the suspension $(100 \mu \mathrm{L})$ was withdrawn through serial dilution; viable cells (colony forming units [CFU]) in the suspension were determined using the spread plate method at a level of detection within 500 CFU per plate. Assays were independently performed with three repetitive tests and data were recorded as means and standard deviations. According to conventional standards [21,22], the borderline of antimicrobial effect was determined to be $1500 \mathrm{mg} / \mathrm{L}$ viable cells $(99.9 \%$ reduction of $\mathrm{CFU}$ ) as the minimum bactericidal concentration (MBC) of antibiotics. A simple comparison of CFU means was carried out ( $t$-test, $p<0.05$ indicated a significant correlation).

\section{Results and discussion}

Fig. 1 gives a TEM image of silver nanoparticles prepared using the in situ reduction method. The average size of the silver nanoparticles was about $40 \pm 8.0 \mathrm{~nm}$. The UV-vis spectrum of the silver nanoparticles is presented in Fig. 2, where we identified that the peak at $410 \mathrm{~nm}$ was the surface plasmon band of the silver nanoparticles synthesized by the in situ reduction.

It is well known that a surface plasmon band of spherical silver nanoparticles appears at around the $400 \mathrm{~nm}$ region. The color

Table 1

Preparation recipe and mixing pattern of Ag-SLN.

\begin{tabular}{|c|c|c|c|c|c|}
\hline Group & $N$ & Sol Ag /liquid (vol/vol, \%) & $\mathrm{Ag}^{\circ}$ dose $(\mathrm{mg} / \mathrm{L})$ & Mixing pattern & Strains tested \\
\hline Control & 15 & 0 & 0 & \multirow{4}{*}{$\begin{array}{l}\text { GC Soft-Liner (GC Soft-Liner, GC cooperation)powder/ } \\
\text { ( } \text { sol } \mathrm{Ag}^{\circ}+\text { conditioner liquid) }=2.2 / 1.8\end{array}$} & \multirow[t]{4}{*}{ E. coli } \\
\hline I & 15 & 0.5 & 1500 & & \\
\hline II & 15 & 1.0 & 3000 & & \\
\hline III & 15 & 2.0 & 6000 & & \\
\hline
\end{tabular}




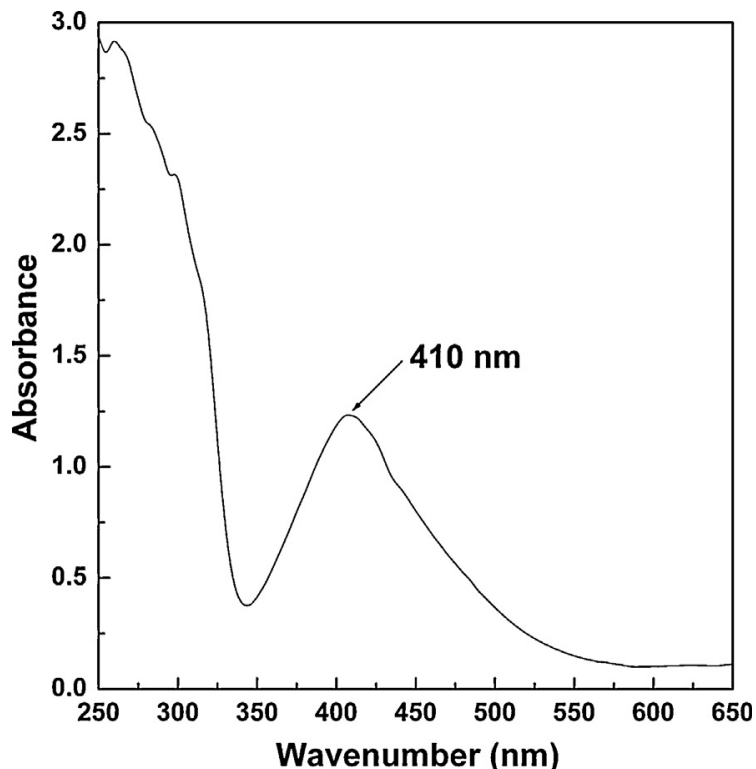

Fig. 2. UV-vis spectrum of silver nanoparticles prepared by the in situ reduction method.

properties of silver nanoparticles are quite sensitive to the size of nanoparticles at a constant number density; at constant mass loading, they appear to be insensitive to small changes in the size of silver nanoparticles because of the inverse cubic coupling between the size of particles and number density at constant mass loading [23]. Therefore, the characteristics of aggregated silver particles are in good agreement with many previous studies [24].

In order to investigate the presence of silver nanoparticles on the surface of Ag-SLN, the FE-SEM and EDAX elemental analysis.

The SEM photographs in Fig. 3 were taken at $250 \times$ magnification to observe the surface morphology of Ag-SLN. Fig. 3 shows the Ag-SLN surface covered with silver particles; the diameter of a silver particle was about 5-50 $\mu \mathrm{m}$. The EDAX spectrum for Ag-SLN is illustrated in Fig. 4. Only carbon, oxygen, and silver peaks can be observed. These have been identified as the principal elements of Ag-SLN. In this case, carbon and oxygen atoms were the main components of the SL. In addition, the peak of the silver atoms showed that silver nanoparticles were immobilized onto the SL surface. Therefore, we confirmed that the silver peak is clearly shown in Fig. 4, which indicates that the silver nanoparticles were successfully immobilized onto the SL surface.

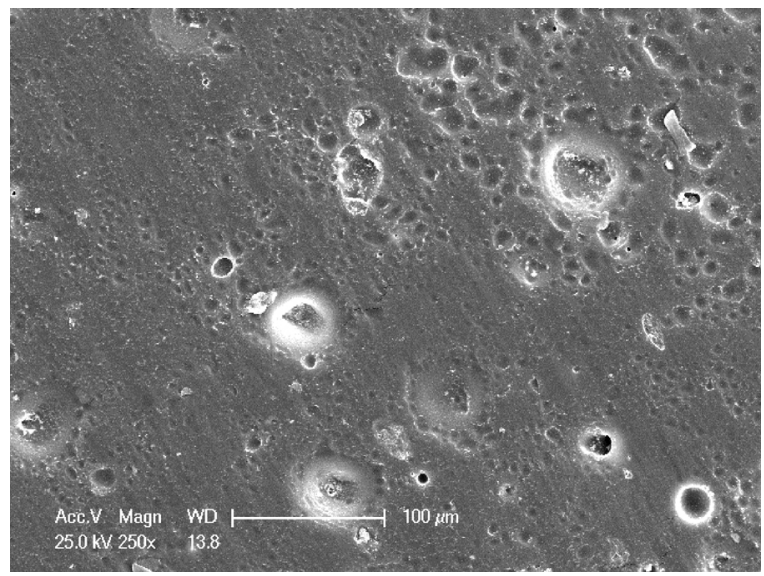

Fig. 3. SEM image of Ag-SLN.

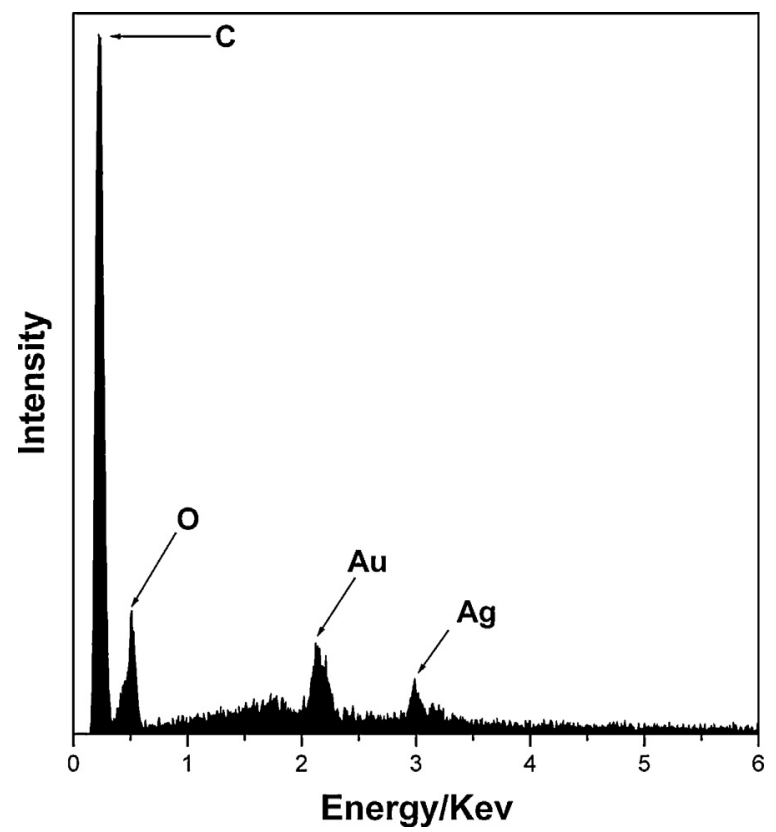

Fig. 4. Energy-dispersive X-ray analysis of Ag-SLN.

SLs are used for short periods to improve the comfort and fit of an old denture until it can be remade or permanently relined. SLs are composed of powder containing poly ethyl methacrylate (PEMA) and a liquid containing an aromatic ester-ethyl alcohol mixture. SLs are very soft elastomers with a hardness of from 13 to 49 Shore A hardness units $24 \mathrm{~h}$ after mixing. The role of liquid is to speed up the polymerization of the monomer at room temperature.

Fig. 5 gives a comparative thermal decomposition pattern for (a) SL, (b) $1500 \mathrm{mg} / \mathrm{L} \mathrm{Ag-SLN,} \mathrm{(c)} 3000 \mathrm{mg} / \mathrm{L} \mathrm{Ag-SLN}$, and (d) $6000 \mathrm{mg} / \mathrm{L}$ Ag-SLN. SL gave two thermal degradation patterns corresponding to the degradation of the ethyl methacrylate and aromatic ester-ethyl alcohol. Fig. 5 shows similar thermograms for (b) $1500 \mathrm{mg} / \mathrm{L} \mathrm{Ag-SLN,} \mathrm{(c)} 3000 \mathrm{mg} / \mathrm{L} \mathrm{Ag-SLN}$ and (d) $6000 \mathrm{mg} / \mathrm{L}$ Ag-SLN from $30{ }^{\circ} \mathrm{C}$ to $600{ }^{\circ} \mathrm{C}$. A sharp weight reduction is observed between $250{ }^{\circ} \mathrm{C}$ and $350{ }^{\circ} \mathrm{C}$.

Despite the use of silver nanoparticles, the onset of degradation for all samples appeared to start at about the same temperature. At the end of the degradation process, the amounts of residues were proportional to the concentrations of silver nanoparticles in SL, since the silver nanoparticles were stable at the experimental temperature. All the samples, including both SL

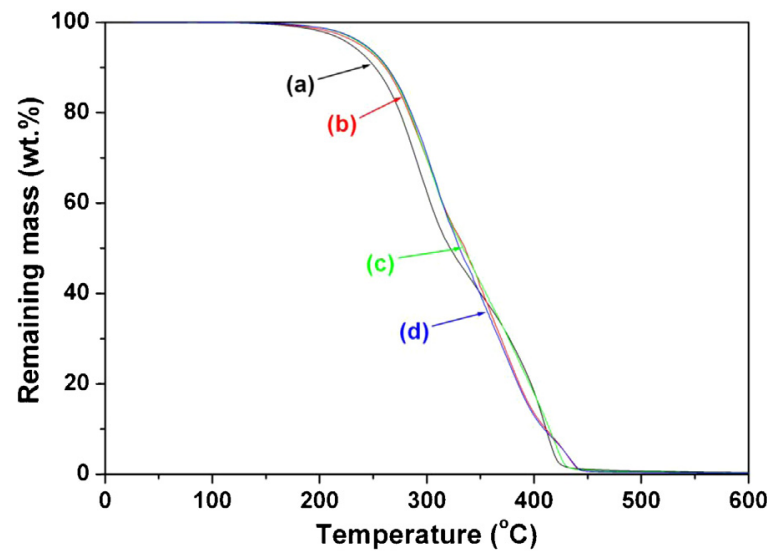

Fig. 5. TGA curves of (a) SL, (b) $1500 \mathrm{mg} / \mathrm{L} \mathrm{Ag-SLN,} \mathrm{(c)} 3000 \mathrm{mg} / \mathrm{L} \mathrm{Ag-SLN}$, and (d) $6000 \mathrm{mg} / \mathrm{L}$ Ag-SLN. 
Table 2

Results for antimicrobial test of Ag-SLN.

\begin{tabular}{|c|c|c|c|c|c|}
\hline \multirow[t]{3}{*}{ Strain (CFU at $0 \mathrm{~h}$ ) } & \multicolumn{5}{|l|}{$\mathrm{Ag}^{\circ}$ dose $(\mathrm{mg} / \mathrm{L})$} \\
\hline & \multirow[t]{2}{*}{ Incubated time $(\mathrm{h})$} & \multicolumn{4}{|c|}{ Mean CFU values \pm (s.d) } \\
\hline & & 0 (Control) & $1500(\mathrm{I})$ & 3000 (II) & 6000 (III) \\
\hline \multirow[t]{2}{*}{ E. $\operatorname{coli}\left(10^{7}\right)$} & 24 & $2.4 \times 10^{8} \pm 1.4 \times 10^{7}$ & $30 \pm 10^{2}$ & 0 & 0 \\
\hline & 72 & $1.7 \times 10^{8} \pm 5.8 \times 10^{7}$ & $80 \pm 10^{3}$ & 0 & 0 \\
\hline
\end{tabular}

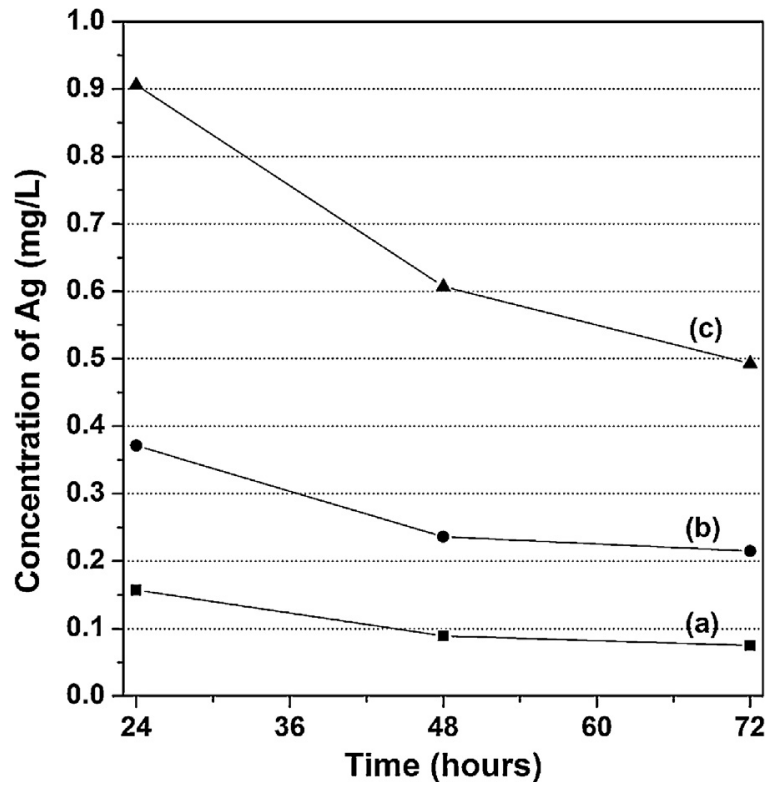

Fig. 6. Release rates of silver into (a) $1500 \mathrm{mg} / \mathrm{L} \mathrm{Ag-SLN,} \mathrm{(b)} 1500 \mathrm{mg} / \mathrm{L}$ Ag-SLN and (c) $1500 \mathrm{mg} / \mathrm{L} \mathrm{Ag-SLN}$.

and Ag-SLN, exhibited a rather similar pattern of degradation. This suggests that silver nanoparticles are uniformly immobilized with SL. In addition, there was a slight sign of thermal stability improvement obtained from the immobilization of the silver nanoparticles.

Fig. 6 shows the release of silver nanoparticles as a function of immersion time in water. It can be seen that for Ag-SLN, a small amount of silver nanoparticles was released. When (a) $1500 \mathrm{mg} / \mathrm{L}$ Ag-SLN, (b) $3000 \mathrm{mg} / \mathrm{L} \mathrm{Ag-SLN}$, or (c) $6000 \mathrm{mg} / \mathrm{L} \mathrm{Ag-SLN} \mathrm{was}$ shaken for 3 days, the remaining silver nanoparticles on the SL was reduced to $0.08 \mathrm{mg} / \mathrm{L}, 0.21 \mathrm{mg} / \mathrm{L}$, and $0.49 \mathrm{mg} / \mathrm{L}$, respectively. In addition, the average release rates of (a) $1500 \mathrm{mg} / \mathrm{L} \mathrm{Ag-SLN,} \mathrm{(b)}$ $3000 \mathrm{mg} / \mathrm{L}$ Ag-SLN, and (c) $6000 \mathrm{mg} / \mathrm{L} \mathrm{Ag-SLN}$ were 0.0017, 0.0035, and $0.0088 \mathrm{mg} / \mathrm{L}$ for $1 \mathrm{~h}$, respectively.

The silver nanoparticle release tests were combined with antimicrobial efficacy tests against $E$. coli in order to determine whether there was a direct correlation. The initial concentration of E. coli was $1.7 \times 10^{7} \mathrm{CFU} \mathrm{mL} \mathrm{m}^{-1}$. After $24 \mathrm{~h}$ and $72 \mathrm{~h}$, the concentration of living $E$. coli in the suspension was measured. The results are summarized in Table 2. When compared to the CFU at $0 \mathrm{~h}$, the control group $\left(0 \mathrm{mg} / \mathrm{L} \mathrm{Ag}^{\circ}\right)$ did not show any microbial inhibitory effect against the strains. For the E. coli bacterial strains, the MBC of the $\mathrm{Ag}^{\circ}$-incorporated samples was identified at doses above $1500 \mathrm{mg} / \mathrm{L}$; no viable cells were detected (no CFU) at conditions of $3000 \mathrm{mg} / \mathrm{L}$ above.

The above results show that the $E$. coli were killed by silver nanoparticles released from the Ag-SLN (bactericidal effect). The $E$. coli survived, but could not grow into colonies on the Ag-SLN surfaces, because in the suspensions taken from the Ag-SLN surfaces silver nanoparticles were present. Therefore, we found that the silver nanoparticles inhibited the growth of E. coli cells.

\section{Conclusion}

This paper reported a new route for the preparation of Ag-ASDL composites as an antimicrobial agent. Our results illustrated the characteristics of Ag-SLN through UV-Vis spectroscopy, TEM, FESEM/EDAX, XRD, AAs, and antimicrobial efficacy tests. The Ag-SLN surface was covered with silver particles and the diameter of the silver particles was about 5-50 $\mu \mathrm{m}$. As a result of thermal analysis, we found that the silver nanoparticles were uniformly immobilized with SL and the Ag-SLN showed a slight sign of thermal stability improvement obtained from the immobilization of the silver nanoparticles. The silver nanoparticle release tests were combined with antimicrobial efficacy tests against $E$. coli. As a result, we found that there was a direct correlation between the release amounts of silver nanoparticles and the antimicrobial effect on $E$. coli. Suspensions of $3000 \mathrm{mg} / \mathrm{L} \mathrm{Ag-SLN}$ and $6000 \mathrm{mg} / \mathrm{L} \mathrm{Ag-SLN}$ showed greater antimicrobial effects (99.9\%) on the E. coli (ATCC 6538). Therefore, we demonstrated a new route for the preparation of AgSLN, and this could be proposed as an antimicrobial dental material.

\section{Acknowledgement}

This research was supported by Kyungpook National University Research Fund, 2011.

\section{References}

[1] J.I. Kroschwitz, Polymers: Biomaterials and Medical Applications, Wiley-Interscience, John Wiley \& Sons, New York, 1989.

[2] Y. Sumi, H. Miura, Y. Michiwaki, S. Nagaosa, M. Nagaya, Archives of Gerontology and Geriatrics 44 (2007) 119.

[3] F.A. Scannapieco, Journal of the American Dental Association 10 (2006) 25.

[4] P.S. Wright, Journal of Dentistry 12 (3) (1984) 19.

[5] S. Qudah, A. Harrison, R. Hugget, International Journal of Prosthodontics 3 (1990) 477.

[6] T. Hamada, H. Murata, Denture Lining, Dental Diamond Co, Tokyo, 2001, pp. 6876 (in Japanese).

[7] L.M. De Visschere, L. Grooten, G. Theuniers, J.N. Vanobbergen, Gerodontology 23 (2006) 195.

[8] L.A. Casemiro, C.H. Gomes Martins, C. Pires-de-Souza Fde, H. Panzeri, Gerodontology 25 (2008) 187.

[9] D.M. Quinn, Journal of Oral Rehabilitation 12 (1985) 177.

[10] M.R. Truhlar, K. Shay, P. Sohnle, Journal of Prosthetic Dentistry 71 (1994) 517.

[11] C.K.W. Chow, D.W. Matear, H.P. Lawrence, Gerodontology 16 (1999) 110.

[12] M. Rai, A. Yadav, A. Gade, Biotechnology Advances 27 (2009) 76.

[13] N.H. Chau, L.A. Bang, N.Q. Buu, T.T.N. Dung, H.T. Ha, D.V. Quang, Advances in Natural Sciences 9 (2008) 241.

[14] T.W. Chang, L. Weinstein, Antimicrobial Agents and Chemotherapy 8 (1975) 677.

[15] B.S. Atyeh, M. Costagliola, S.N. Hayek, S.A. Dibo, Burns 33 (2007) 139.

[16] D. Roe, B. Karandikar, N. Bonn-Savage, B. Gibbins, J.B. Roullet, Journal of Antimicrobial Chemotherapy 61 (2008) 869.

[17] P. Jain, T. Pradeep, Biotechnology and Bioengineering 90 (2005) 59.

[18] T.T.N. Dung, N.Q. Buu, D.V. Quang, H.T. Ha, L.A. Bang, N.H. Chau, N.T. Ly, N.V. Trung, Journal of Physics: Conference Series 187 (2009) 012054.

[19] E. Budtz-Jørgensen, E. Theilade, J. Theilade, H.A. Zander, Scandinavian Journal of Dental Research 89 (1981) 149.

[20] J. Chandra, P.K. Mukherjee, S.D. Leidich, F.F. Faddoul, L.L. Hoyer, L.J. Douglas, M.A. Ghannoum, Journal of Dental Research 80 (3) (2001) 903.

[21] W. Bruns, H. Keppeler, R. Bancks, Antimicrobial Agents and Chemotherapy 27 (1985) 632.

[22] A.G. Gristina, R.A. Jennings, P.T. Naylor, Q.N. Myrvik, L.X. Webb, Antimicrobial Agents and Chemotherapy 33 (1989) 813.

[23] C. Advait, S. Praveen, S. Suvarna, T. Rochish, M. Anurag, Colloids and Surfaces A: Physicochemical and Engineering Aspects 404 (2012) 83.

[24] L. Suber, I. Sondi, E. Matijevi, D.V.J. Goia, Journal of Colloid and Interface Science 288 (2005) 489 